\title{
IBN KHALDUN DAN PEMIKIR SOSIAL BUDAYA
}

\section{Oleh M. Zainuddin \\ Prnulis adalah Dosen STAIN Malang dan Ketua Penerbitan STAIN Malang}

Pusat Riset Sosial dan Kriminal Nasiorial (Al-Markaz al-Qaumy lil-Bubuts alIjtima'iyyab wal-Jinaiyyah) telah menadakan penelitian tentang pemikiran sosial Ibn Khaldun. Organisasi ini telah mengalakaln simposium dalam rangkal memperingati Ibn Khaldun yang dihadiri oleh puluhan ilmuwaln yang menalruh perhatian besar dalam kajjian pemikirannyal. Mereka hadir dari sembilan negalara : RPA, Túnisia, Al-Jazair, Irak, Libanon, Turki, Italial, Perancis clan Jerman Barat. Kepalda setiap peserta diminta membuat satu pembahasan menurut tema yang telah diprakarsai oleh wakil Kepala Negara Sayid Husein As-Syari'i yang berlangsung sejak tanggal 2-5 Januari 1961. Dan di depan Kantor Pusat Riset Sosial dan Kriminal Nasional yang terletak di kotal Auqaf itu clibangun patung Ibn Khaldun untuk mengenang jasal besarnyal.

Begitu besar nama Ibn Khaldun sehinggal dunia mengakui clan mengkaji kembali pemikiran-pemikirannyal. Jikal kital menguak kembali khazanah pemikiran intelektual Islam abald pertengalhan dan mengembangkan tradisi pemikiran di dunia kampus salyal kiral tradisi dan budaya ini bagus untuk dilakukan.

Siapakah sesungguhnya sosok Ibn Khaldun itu? Dan bagaimanal pemikirannya? Inilah yang hendak kital kalji (hanyal di sini dibatasi pala pemikiran sosial budalyanyal saljal).

\section{Sekilas tentang Ibn Khaldun}

Nama lengkalp Ibn Khaldun adalah Abu Zaid Aburrahman bin Muhammad bin Khaldun Waliuddin At-Tunisi al-Hadhrami lahir di Tunis padal tanggal 1 Ramaldhan $732 \mathrm{H}$ (7 Mei 1332M). Ia dibesalrkan di tengah gejolak galaunya politik, kemandekan pemikiran dikalangan umat, perebutan kekualsalan dan disintegrasi. Dalam lingkungan seperti inilah Ibn Khaldun nemperoleh pendidikan agama, bahalsal, sastra serta filasafat. Sejak muda ia sudah terjun di dunia politik yang mengalwali karier politiknya sebagai pegalwai rendah keraljalan (tukalng setempel) pacla pemerintahan Muhammal Ibn Talfrakin. Kemudian meningkat menjadli sekretaris sultan Abu Inan di Tilamsan. Karrena didugal keras hendak menjatuhkan sultan, maka ia pun dipenjarakan selama dua tahun (1357M). Banyak jabatan yang dipegang semalsa mudanya. Pernah menjadi sekretaris dan penasihat kerajalan Maroko yang dipimpin oleh sultan Abu Salim pada tahun 1389M. Disamping pernah menjabat sebagai Perdanal Menteri di Bijaiyalh, ial juga pernah menjadi Ketua Pengadilan kerajalan di Mesir dan Dosen ilmu Hukum di tenpat yang sama. Petualangan politiknyal begitu jaluh hingga banyak lawan persaingannyal. Selama kurang lebih 25 tahun ial sering berpindah-pindah darri negeri saltu ke negeri lain hingga sampai ke Andalusia. Pacla tahap kehiclupan ini sebalgian walktunyal dihabiskan untuk mengabdi kepada pemerintah dan clunial politik.

Setelah mengabdi dari pemerintahan satu ke pemerintahan yang lain, Ibn Khaldun merasa jenuh untuk kemuclian ia mengkonsentrasikan pemikiranya padal penulisan. Tahap ini berlangsung kurang lebih selama delapan tahun. Empat tahun pertama 
dijalaninya di benteng Ibn Salamah clan empat tahun sisanya di Tunisia. Pada tahun ini Ibn Khaldun bena-benar mencurahkan pikirannya untuk menulis kitab Al-'Ibar wa diwan al-Mubtada wal Akbbar fi Ayyam al 'Arab wal-'Ajam wal-Barbar wa man 'Asbrabum min. Dzawis Sulthan al-Akbar yang terdiri clari buku inilah yang sekarang dikenal dengan Mugaddimab Ibn Kbaldun.

Sebagaimana orang-orang dahulu pada zamannya, Ibn Khaldun memang sosok yang piawai clan memiliki banyak disiplin ilmu. Ia tidak hanya dikenal sebagai ahli sejarah dan sosiologi, tetapi juga sastra, pedagogi, ilmuilmu hadits, fiqh dst. (Lihat juga, The Encyclopedia of Pbilosopby : 107).

\section{Tentang Kitab Muqaddimah}

Muqaddimah adalah merupakan kitab pendahuluan dari ketujuh jilid kitab sejarah clunia yang ia tulis, yaitu kitad Al-Ibar wa Diwan al-Mubtada ... Karya Ibn Khaldun ini tergolong karya tulis klasik yang memiliki pembahasan sistematis dan metodologis. Pada bagian pertama (pengantar) ia jelaskan alasanalasan pemikirannya, sistematika dan metodemetodenya. Demikian pula clibuat persembahan yang dipersembahkan untuk Amir al-Mu'minin Abu Faris Abclul Aziz bin Abi Al-Hasan al-Muriniy (Sultan Maghrib al$A q s b a)$. Pada bagian pendahuluan dijelaskan tentang: kelebihan ilmu sejarah, verifikasi aliran-alirannya, tentang kesalahan-kesalahan yang. dilakukan oleh para sejarawan serta faktor-faktornya. Karya ini terdiri dari enam bab. Bab pertama membahas masyarakat manusia clan menekankan pentingnya masyarakat manusia tersebut; bab kedua membahas tentang masyarakat nomaclen (baclui, badawa!̣); bab ketiga membahas tentang negara, raja pemerintahan clan tingkat kesultanan; bab keempat membahas tentang negara dan kota serta tempat tinggal.

Ibn Khalclun begitu intens mangkaji masalah-masalah fenomena sosial yang selalu berubah menurut konclisi yang mempengaruhinya. Oleh sebab itu menurutnya, seorang sosiolog harus teliti terhadap perubahan yang terjadi dalam madsyarakat, sebagaimana katanya :

...Banyak sekali orang yang membacal atau mendengar catatan-catatan tentang kejadian masa lalu, dan mielupakan perubahan-perubahan besar, malahan melupakan revolusi-revolusi yang terjadi dalam keaclaan-keadaan dan lembagalembaga selama itu, lalu mengambil-persaan antara kejadian-kejadian masă lalu itu, sambil memberi hukum mengenai barang yang sudah lalu dengan apa yang mereka ketahui ketika itu. Padahal perbedaan antara dua periode itu mungkin banyak, sehingga membawanya pada kesalahan besar. (Lihat Muqaddimab: 29).

Secara umum Ibn Khaldun melihat fenomena sosial yang. ia istilahkan dengan waqiat al-umran al-Basyariy atau abwal alijtrima' alinsaniy sebagai kaidah-kaidah dan kecenderungan umum yang dibentuk oleh individu-individu satu masyarakat sebagai dasar dalam mengatur masalah-masalah sosial yang terjadi di antara mereka, serta mempererat hubungan-hubungan yang mengikat mereka satu sama lain dan yang mengikat mereka clengan orang selain golongan mereka. Hakikat sejarah menurutnya aclalah :

Catatan tentang masyarakat umat manusia atau peradaban dunia; tentang perubahan-perubahan yang terjadi pacla watak masyarakat tersebut (Lihat Muqaddimab: 35).

Menurut Ibn Khaldun fenomena sosial itu 
ticlak berbecla clengan fenomena alam yang lain. Oleh sebab itu ia melihat bahwa fenomena sosial itu tuncluk kepadal hukumhukum itu sendiri. Masyarakat manusia menurut Ibn Khaldun adalalh suatu entitas yang independen dan dapat diurus secaral sempurna lepas clari nilai-nilai agama (Baali, 1989:159).

Jauh sebelumnya Ibn Khaldun sudah mangkaji masalah sosiologi peclesalan dan perkotalan. Ini terbukti pada pembahasannya tentang masyarakat badawab clan masyarakat badharab. Menurutnya, masyarakat badawab, pedesaan, pedalaman adalah masyarakat yang masih mengutamakan hubungan darah, semangat primordialisme (ashabiyab), dimana masyaralkat dikontrol oleh motivasi mereka sendiri yang muncul secara spontan. Berbeda dengan masyalrakalt kota, maka kekuatan, police di jadlikan sebagai kontrol sosial (Báali, 1989:159).

Dalam mengkaji perbedaan sifat-sifat manusia kota (badharab) dengan manusial desa (nomaden, badawah), seperti adanya kecenderungan ilmiah, keterampilan dan kerendahan diri, kebuasan clan kebanggan diri mereka, Ibn Khaldun sampai kepada berkesimpulan bahwa masyarakat kotal sama sekali tidak lebih baik dari masyarakat clesal (nomad).

Sebagaimana analisis Báali (1989:160), bahwa deskripsi Ibn Khaldun tentang ashabiyab nomaden ternyatal sangat mirip clengan deskripsi Durkheim tentang soliclaritas mekania. Dan menurut Ibn Khaldun bahwa lemahnyal ashabiyab kalangan masyarakat kotal (berperaclaban) meunjukkan tindakan bunuh diri yang bakal terjadi pada masyarakat secara keseluruhạn. Bàgi Ibn Khaldun, orangorang nomad memiliki moral yang kuat dan lebih mendekati semangat agama ketimbang masyarakat kota. Perbuatan jahat dan kebejatan moral yang meningkat clalam masyarakat kota jarang terjadi pada masyarakat nomad. Distruksi sosial dalam masyarakat kota akibat penggunalan kekuatan clalam kostrol sosial.

Ibn Khaldun nampaknya lebih megutamakan nomadisme berdasarkan nilainilai yang ada pada dirinya. Menurutnya manusia bisa baik clan jahat pacla salat yang sama. Manusia jahat karena adlanya sifat clasar kebinatangan, dan sebaliknya, manusia itu baik karena keterlibatannya dengan manusia lain (Lihat Muqaddimab: 127, 142,143). Oleh sebab itu menurut Ibn Khaldun semakin kuat keterikatan manusia dalam suatu kelompok akan semakin baik baginya, karena sifat sosialnya akan kuat clan clapat memperkecil sifalt kebinatangannya. Di sini jelas Ibn Khaldun memberi tekanan pala proses sosialisasi, khususnya mengenai pergaulan penting sesama manusia. (Lihat pula Ilyas Bà Yunus \& Farrid Ahmad, $1988: 41$ ).

Ibn Khaldun juga mengatakan, bahwal digunakannya kekuasaan untuk tujuan kontrol sosial membuat manusial sangat mungkin ticlak jujur dan clusta. Untuk menghindari tekanan dari pemerintah/penguasa, manusia kotal cenclerung menyembunyikan sifat yang sesungguhnya Ibn Khaldun juga mencatait, bahwa peradaban biasanya clekat dengan kemewahan yang pada gilirannya menimbulkan penipuan, pencurian, perjudian, perzinaan clan segala macam praktek destruktif lainnya. Kemajuan masyarakat desa sudah terbiasal dengan kehiclupan yang sederhana clan jauh dari kemewahan, bedonisme ((Baali, 1989:161162).

Teori perkembangan masyarakat bagi Ibn Khaldun adalah bahwa faktor perkembangan masyarakat disebabkan karena adanya perbedaan tata pemerintahan. Penguasa 
memiliki peran besar clalam membentuk perkembangan masyarakat, sampai kepadal masalah agama mereka lebih cenclerung manut kepada penguasa/raja. Manusial mengikuti algamal Pemimpinnya (lihat Muqaddimab 29). teori ini mirip dengan yang clipakai oleh psikolog clan sosiolog modern seperti Magdlogal (Inggris) clan Tard clari Perancis yang mengaltakaln, bahwal faktor yalng menyebabkan timbulnyal perkembangan clalam masyarakat berasal clari hasil kerja/ rekalyasal parar pemimpin, para pembaharu dan ahli pikir (A.A. Waffi, 1985:135).

Ibn Khaldun memandang, bahwa kehiclupan umat (jama'ah) aldalah berubahubah clalam bentuk yang berbecla-becla, misalnyal dari kehiclupan badalwah, badui membentuk kabilah-kabilah dan suku bangsal clan pala akhirnya membentuk negara dalam suatu kota. Kemewahan mendorong manusial untuk melenyapkan keperwiraln yang sebelumnya mereka miliki dan palda gilirannyal menghancurkan spiritualitas clan solidaritas kelompok mereka (De Boer : 275).

Demikian pengamatan Ibn Khaldun begitu jeli terhadap perkembangan masyarakalt yang senantiasal berubah clan clinamis itu. Pengamatan Ibn Khaldun tersebut sebalgian besar tepalt clan berlaku bagi masyalrakat sekarang yang sudah modern.

Teori fenomena sosial Ibn Khaldun termasuk teori evolusi yang memandang fenomena sosial sebagai clinamis, berbedabecla clarri bangsal satu clenagn bangsal yang lain, berbecla pula menurut generasi saltu ke generasi yang lain. Kenyatalan ini juga berlaku cli biclang-biclang : sosial, ekonomi maupun politik, bahkan soal etika. Sesuatu yang clianggap baik oleh masyarakat clulu mungkin jelek bagi masyarakat sekarang clan sebaliknyal, begitu jugal mengenai normanorma. Sesuatu yang clulu. di anggap tabu sekalrang menjacli hal yang bialsal, lumrah. Inilah kelebihan Ibn Khaldun di clalam mencermati gejala/fenomena-fenomena sosial. Ia menyebutkan :

"Sesungguhnyal ihwal clunia, bangsalbangsal, aclat clan kepercalyalan merekal ticlak statis, ial berjalan di atals satu tatanan tetap. Setiap hari clan setiap zaman ia berubah-ubah dan berpinclah-pinclah clari sattu keallalan ke keadalan yang lain sebagaimanal yang terjadi pacla incliviclu-inclividu, waktu clan kotal, clemikianlah yang terjacli clalam provinsi, tempat, zaman clan negara" (Muqaddimab: 28

\section{DAFTAR PUSTAKA}

Ali Abclul Wahicl Waffi, Ibn Khaldun: Riwayat dan Karyanya, terj. Ahmadli Tohal, Jakalrta : Grafiti, 1985.

Fuad Baali dan Ali Wardi, Ibn Kbaldun and Islamic Thought A Social Perspective, Hall\&Co, Boston, Malssachussette, 1981 clan terjemahan Ahmadli Tohal, Jakarta Pustakal, 1989.

Ilyas Ba Yunus dan Farricl Tohal, Sosiologi Islam dan Masyarakat Kontemporer, Bandlung : Mizan, 1988.

Ibn Khaldun, Muqaddimab, Mesir, tt. Maktabah Musthafa Muhammad. 